\title{
POLITIK HUKUM OMNIBUS LAW DALAM KONTEKS PEMBANGUNAN EKONOMI INDONESIA
}

\author{
Agus Darmawan \\ Universitas Muhammadiyah Tangerang, \\ Magister Hukum \\ Jalan Perintis Kemerdekaan I Babakan No.33, RT.007/RW.003, Cikokol, Kec. Tangerang, Kota Tangerang, Banten \\ 15118 \\ *agus.gic@gmail.com
}

\begin{abstract}
The research aims to formulate the politics of the omnibus law law as an effort by the Government to increase investment to advance the economy and prosperity of all Indon people. This study uses a normative approach. The results showed that the omnibus law had not been formulated effectively and accountably so that it needed improvement. The formulation and implementation of the Omnibus Law, it must be balanced at the level of effectiveness and accountability by paying attention to the juridical, political, sociological and economic aspects. Advocacy from all elements of the nation at the level of formulation and implementation of the omnibus law will effectively realize increased investment in economic development for the welfare of all the people of Indonesia.
\end{abstract}

KEYWORDS Law Politics, Omnibus Law, and Economic Development

\section{INTRODUCTION}

Politik hukum diartikan sebagai kebijakan dasar penyelenggara negara dalam bidang hukum yang akan, sedang dan telah berlaku, yang bersumber dari nilai-nilai yang berlaku di masyarakat untuk mencapai tujuan negara yang dicita-citakan.(Frenki, 2011; Wahyono, 1984) Tujuan dari politik hukum nasional adalah sebagai alat (tool) atau sarana dan langkah yang dapat digunakan oleh pemerintah untuk menciptakan suatu sistem hukum nasional yang dikehendaki dan dengan sistem hukum nasional itu akan diwujudkan cita-cita bangsa Indonesia yang lebih besar.(Prasetyo, 2016; Syaukani \& Thohari, 2013)

Pada tataran empiris, Moh. Mahfud MD mempergunakan politik hukum sebagai pendekatan dalam memahami relasi antara hukum dan politik, serta mendefinisikan politik hukum sebagai arah kebijakan hukum (legal policy) yang di buat secara resmi oleh negara tentang hukum yang akan diberlakukan atau tidak akan diberlakukan untuk mencapai tujuan negara. Hukum ditempatkan sebagai alat untuk mencapai tujuan negara sehingga pembuatan hukum baru atau pencabutan hukum lama oleh negara harus dijadikan langkah untuk mencapai tujuan negara.(Mahfud Md, 2006) Menurut Pablo Holmes, politik dan hukum harus memiliki korelasi yang sejalan namun bukan sebagai instrumen untuk mendukung kemauan eksekutif atau pemerintah yang sedang berkuasa.(Holmes, 2014) 
Salah satu tujuan negara yang dimuat dalam Pembukaan UUD 1945 adalah tercapainya kesejahteraan masyarakat Indonesia.(Suhardin, 2007) Untuk itu, pondasi perekonomian Indonesia perlu diperkuat salah satunya dengan cara menarik investor untuk sebesarbesarnya berinvestasi di Indonesia.(Kurniati, 2018) Masuknya investasi di Indonesia diharapkan akan mendorong penciptaan lapangan kerja yang seluas-luasnya untuk seluruh rakyat Indonesia. Perlu adanya inovasi dari Pemerintah untuk menarik investor, salah satunya melalui penyederhanaan dan perampingan peraturan atau yang kita kenal sebagai Omnibus Law.(Tohadi, 2020)

Omnibus Law/RUU Cipta Kerja yang saat disusun Pemerintah menjadi program unggulan Pemerintahan Jokowi-Ma'ruf Amin demi menggenjot pertumbuhan ekonomi dan masuk dalam Prolegnas Prioritas 2020. (Mayasari, 2020) Sejumlah kalangan mengkritik pembentukan Omnibus law ini dengan beragam alasan dan argumentasi terkait metode penyusunan satu regulasi (UU) baru sekaligus menggantikan/menghapus beberapa pasal dalam satu regulasi atau lebih yang berlaku. Namun demikian, tidak sedikit kalangan mendukung pembentukan Omnibus Law ini sebagai salah satu strategi reformasi regulasi mengatasi kondisi obesitas/hiper regulasi, khususnya di sektor kemudahan berusaha.(Anggono, 2020)

Apabila dicermati, ada beberapa implikasi negatif dari pembentukan Omnibus Law (RUU Cipta Lapangan Kerja), antara lain merugikan pekerja, merugikan bidang pertanian, monopoli tanah, memangkas dan mengubah konsep administrasi, pendidikan yang berorientasi pasar, dan adanya ketidaktrasnparanan. Dalam konteks merugikan pekerja, Omnibus Law merugikan pekerja karena: i) memperpanjang jam kerja dan lembur; ii) penetapan upah minimum yang rendah; iii) adanya potensi terjadi pelanggaran hak berserikat pekerja; iv) adanya pemangkasan kewenangan serikat pekerja; dan hilangnya hak-hak pekerja perempuan untuk cuti haid, hamil dan keguguran.

Omnibus Law juga dikhawatirkan akan memangkas dan mengubah konsep syaratsyarat administrasi, hal ini terkait dengan praktek usaha yang akan menyebabkan kerusakan/mengubah fungsi ruang atau lingkungan, antara lain: adanya sentralisasi kebijakan, menghilangkan pelibatan masyarakat, flexibilitas dan penyesuaian tata ruang, penghilangan izin mendirikan bangunan, reduksi atas subtansi AMDAL, dan penghapusan sanksi pidana lingkungan.

Omnibus Law pada satu sisi juga akan berimplikasi pada langgengnya praktik pendidikan yang berorientasi pada pasar, seperti: komersialisasi, link and match pada dunia industri, dan pembentukan kurikulum pendidikan yang berorientasi kerja. Fokus pada penulisan artikel ini adalah bagaimana poliltik hukum Omnibus Law dalam rangka pembangunan ekonomi dalam konsep negara kesejahteraan dan bagaimana kerangka hukum Omnibus Law ideal untuk menggerakkan perekonomian dan investasi untuk mewujudkan kesejahteraan seluruh rakyat Indonesia

Penelitian "Politik Hukum Pembentukan Super Holding Badan Usaha Milik Negara Indonesia Dalam Perspektif Negara Kesejahteraan" menggunakan beberapa teori yang akan dipakai sebagai alat analisis penelitian dalam grand theory, middle range theory dan applied theory. Pada tataran grand theory dipilih teori negara kesejahteraan (welfare state). Pada 
middle range theory dipilih teori politik hukum, sedangkan pada applied theory dipilih teori hukum pembangunan oleh Mochtar Kusumaatmadja.

Dari latar belakang sebagaiman telah diuraikan di atas, dimana ide pembentukan Omnibus Law (RUU Cipta Lapangan Kerja) yang dilakukan pemerintah menimbulkan polemik di masyarakat, maka penulisan ini akan meninjau kembali politik hukum berkenaan Omnibus Law dalam konteks pembangunan ekonomi Indonesia. Dan fokus penulisan artikel ini adalah bagaimana poliltik hukum Omnibus Law dalam rangka pembangunan ekonomi dalam konsep negara kesejahteraan dan bagaimana kerangka hukum Omnibus Law ideal untuk menggerakkan perekonomian dan investasi untuk mewujudkan kesejahteraan seluruh rakyat Indonesia.

\section{METHODOLOGY}

Sifat penelitian dalam penulisan ini adalah deskriptif yang dilakukan dengan pendekatan yuridis normatif. Jenis dan sumber data yang digunakan adalah data sekunder. Pengumpulan data dilakukan terutama dengan teknik studi dokumen (library research and online research) dengan menginventarisasi data sekunder yang diperlukan, baik berupa bahan hukum primer, sekunder maupun tersier, kemudian melakukan penelusuran sejarahnya dan sinkronisasi antar bahan hukum tersebut.

Bahan hukum primer yang dipergunakan terdiri dari peraturan perundang-undangan terutama yang berkaitan dengan penyusunan peraturan perundang-undangan dan peranan hukum dalam pembangunan ekonomi. Bahan hukum sekunder yang akan digunakan digunakan antara lain berupa: karya ilmiah, hasil penelitian dan literatur yang berkaitan dengan substansi penelitian. Bahan hukum tersier, yaitu bahan-bahan yang menunjang informasi bahan hukum primer dan sekunder, antara lain data dari surat kabar, jurnal, kamus, ensiklopedia.

Penelitian ini pada dasarnya berkaitan dengan bagaimana menyusun Omnibus Law dalam konteks menarik investor dan meningkatkan pembangunan ekonomi Indonesia dalam rangka mewujudkan kesejahteraan seluruh rakyat Indonesia dapat terwujud.

\section{RESULTS AND DISCUSSION}

Konsep Omnibus Law dikenal juga dengan omnibus bill yang sering digunakan di Negara yang menganut sistem common law seperti Amerika Serikat dalam membuat regulasi. Regulasi dalam konsep ini adalah membuat satu UU baru untuk mengamandemen beberapa UU sekaligus.

Tumpang tindih regulasi akan berimplikasi pada iklim investasi di Indonesia, sebagai contoh ketika ada usulan memperbaiki regulasi di bidang kehutanan maka yang harus direvisi adalah UU No. 41/1999 tentang Kehutanan. Namun, masih ada ganjalan dalam peraturan lain, semisal UU No. 32/2009 tentang Perlindungan dan Pengelolaan Lingkungan Hidup (PPLH) atau UU No. 5/1960 tentang Peraturan Dasar Pokok-Pokok Agraria.

Konsep Omnibus Law diharapkan mampu menjawab persoalan tumpang tindih aturan perundang-undangan di Indonesia. Namun demikian, konsep Omnibus Law yang biasanya 
diterapkan di negara yang menganut sistem common law agak sulit ditetapkan di Indonesia yang menganut sistem civil law.

Pada dasarnya terdapat persoalan konflik antara penyelenggara pemerintahan, saat ingin melakukan inovasi atau kebijakan yang kemudian berbenturan dengan peraturan perundang-undangan. Omnibus Law yang dilakukan dalam tingkatan UU menjadi salah satu jalan keluar yang dapat diambil pemerintah untuk mengatasi konflik dimaksud.

Konsep Omnibus Law dapat digunakan di Indonesia untuk penyeragaman kebijakan pusat dan daerah dalam menunjang iklim investasi, dimana konsep ini menjadi cara singkat sebagai solusi peraturan perundang-undangan yang saling berbenturan, baik secara vertikal maupun horizontal.

Dari hasil penelitian, permasalahan yang timbul dari Omnibus Law ini adalah terkait kedudukan UU hasil Omnibus Law tersebut. Secara teori perundang-undangan di Indonesia, kedudukan UU dari konsep Omnibus Law ini belum diatur. Apabila melihat sistem perundang-undangan di Indonesia, UU hasil konsep Omnibus Law bisa mengarah sebagai "UU Payung" karena mengatur secara menyeluruh dan kemudian mempunyai kekuatan terhadap aturan yang lain. Namun demikian, Indonesia tidak menganut UU Payung karena posisi seluruh UU adalah sama.

Secara teori peraturan perundang-undangan, akan timbul permasalahan terkait kedudukannya dan hal ini harus diberikan legitimasi dengan merevisi UU No 12 Tahun 2011 tentang Pembentukan Peraturan Perundang-undangan. Apabila UU No. 12 Tahun 2011 tidak direvisi, harus dilihat bagaimana isi ketentuan di dalam UU Payung tersebut, apakah bersifat umum atau lengkap seperti UU biasa. Apabila bersifat umum, maka tidak semua ketentuan dilakukan pencabutan, namun yang dicabut hanya yang bertentangan saja. Ketentuan yang bersifat umum akan menimbulkan permasalahan apabila dibenturkan dengan asas lex spesialis derogat legi generalis (aturan yang khusus mengesampingkan aturan yang umum), karenanya perlu diatur dalam hierarki perundang-undangan perihal kedudukannya.

Dalam konsepsi otonomi daerah, perlu dihindari agar Omnibus Law tidak bertentangan dengan apa yang menjadi kewenangan daerah yang tertuang dalam Peraturan Daerah dalam mengatur daerahnya. Untuk itu, adanya Omnibus Law harus secara bersamaan dan secara otomatis bahwa peraturan tingkat daerah juga harus mematuhi aturan baru dari konsep Omnibus Law.

Konsep Omnibus Law dimaksudkan untuk memudahkan investor untuk menanamkan modal di Indonesia. Sebagai catatan bahwa kemudahan berusaha di Indonesia atau Ease of Doing Business (EODB) secara berangsur-angsur terus menunjukkan perbaikan signifikan, dimana pada tahun 2016 berada pada peringkat 106, saat ini sudah di peringkat 91.

Namun demikian, dalam merumuskan Omnibus Law perlu kajian yang mendalam dalam perspektif hukum dan ekonomi, sehingga apa yang diharapkan dan menjadi tujuan dalam konsepsi Omnibus Law untuk meningkatkan investasi dan kesejahteraan seluruh rakyat Indonesia dapat terwujud.

\section{Omnibus Law Sebagai Stimulus Investasi Dalam Konteks Negara Kesejahteraan}


Pilihan berfikir yuridis yang dipilih dalam penulisan ini bermuara dari teori tentang tujuan eksistensi sebuah negara. Beberapa teori yang dikenal dalam eksistensi sebuah negara yang terkenal antara lain konsep mengenai negara hukum dan konsep negara kesejahteraan. Dalam konsep negara hukum, negara menjalankan aktivitasnya dengan koridor berbagai perangkat hukum. Sedangkan, dalam konsep negara kesejahteraan (welfare state), peran negara menjadi dominan dalam setiap aspek kehidupan rakyat demi terwujudnya kesejahteraan sosial. Emmanuale Pavaloni dan Costanzo Ranci, menyatakan bahwa beberapa negara di wilayah eropa barat telah melakukan reformasi hukum dalam kurun waktu yang panjang untuk mendukung perwujudan peningkatan kesejahteraan rakyatnya.(Pavolini \& Ranci, 2008)

Tujuan negara di dalam konsep negara kesejahteraan adalah untuk kesejahteraan umum. Negara mengorganisasikan kekuasaan untuk mengendalikan administrasi dan politik untuk memodifikasi pasar untuk kesejahteraan sosial dan kemampuan ekonomi dari masyarakatnya. Haksoon Kim, dalam penelitiannya menyampaikan bahwa kesetabilan politik yang tercipta akan menciptakan iklim investasi yang baik untuk menarik investor asing. Dalam pembangunan ekonomi khususnya pengembangan investasi yang merupakan perwujudan tanggung jawab negara dalam dalam kerangka welfare state, maka regulasi Omnibus Law (UU Cipta Lapangan Kerja) sebagai upaya menarik investor untuk berinvestasi di Indonesia harus memberikan adanya kepastian hukum dalam merumuskan Omnibus Law dimaksud.(Kim, 2010)

Negara kesejahteraan merujuk pada suatu model yang ideal dari pembangunan yang berfokus pada peningkatan kesejahteraan melalui pemberian peran yang penting dan lebih besar kepada negara untuk memberikan pelayanan sosial secara menyeluruh dan komprehensif kepada warganya. Paul Spicker menyatakan bahwa “...stands for developed ideal in which welfare is provided comprehensively by the state to the best possible standards". Pembangunan ekonomi sangat mempengaruhi tingkat kemakmuran suatu negara. Kebijakan pemerintah bertujuan untuk mengubah kondisi negara ke arah yang lebih baik.

Pembangunan ekonomi sebagai wujud keikutsertaan negara dalam upaya pembangunan ekonomi untuk meningkatkan kesejahteraan masyarakat. Jhon Maynard Keynes manyatakan bahwa keikutsertaan negara merupakan jawaban atas kondisi ketidaksempurnaan pasar (market imperfection) yang menuntut peranan pemerintah yang lebih besar dalam fungsinya sebagai agent of development termasuk dalam hal pengelolaan investasi pemerintah. (Sastradipoera, 2007) Namun demikian, Rian Duchin dan Denis Sosyura, menyatakan intervensi pemerintah perlu dibatasi agar tidak mengganggu mekanisme pelaksanaan investasi yang ada.(Duchin \& Sosyura, 2012)

Menurut ahli ekonomi China, Shimin Chen intervensi pemerintah yang tepat akan meningkatkan efektifitas dalam perekonomian, seperti halnya yang terjadi dalam pengelolaan BUMN di China dimana intervensi pemerintah dalam memperbaiki tata kelola BUMN dapat meningkatkan efisiensi perusahaan tersebut, sebaliknya apabila intervensi yang dilakukan tidak tepat, misalnya memasukkan kepentingan politik dalam pengelolaan BUMN akan berdampak buruk pada kinerja perusahaan. Dalam konteks pembangunan ekonomi, keikutsertaan pemerintah bertujuan untuk meningkatkan kesejahteraan rakyatnya. (Chen et al., 2011) 
Kebijakan ekonomi yang diterjemahkan dalam regulasi harus berorientasi pada kesejahteraan. Stephen K. Aikins menyatakan bahwa dalam krisis ekonomi global, pemerintah harus membuat regulasi di bidang ekonomi untuk mewujudkan kesejahteraan. Konsepsi Omnibus Law sebagai suatu undang-undang yang menyasar satu isu besar yang mungkin dapat memangkas dan atau merevisi suatu undangundang telah diterapkan di beberapa negara.(Aikins, 2009)

Kanada menggunakan pendekatan Omnibus Law untuk mengimplementasikan perjanjian perdagangan internasional, dimana negara ini memodifikasi 23 undangundang lama agar dapat tunduk kepada aturan World Trade Organization.

Penggunaan Omnibus Law juga pernah dilakukan Filipina, dimana negara ini konteksnya mirip dengan di Indonesia yaitu dalam hal investasi. The Omnibus Investment Code merupakan serangkaian peraturan yang memberikan insentif komprehensif baik fiskal maupun non-fiskal yang dipertimbangkan oleh pemerintah Filipina dalam rangka pembangunan nasional. Selain Filipina, beberapa negara yang juga pernah menerapkan konsepsi Omnibus Law adalah Turki, Selandia Baru, Australia dan Vietnam.

Turki menggunakan omnibus untuk melakukan amandemen terhadap peraturan perpajakan. Aspek yang diamandemen antara lain PPh, PPN, belanja pajak, tabungan pension, jaminan sosial dan asuransi kesehatan. Pada Tahun 2019, Turki menerbitkan Omnibus Law nomor 7161 yang membuat beberapa amandemen penting seperti penambahan perbedaan mata uang sebagai basis PPN, menjadikan "rasio harga konsumen" sebagai dasar untuk menentukan kenaikan harga leasing, serta pembebasan $70 \%$ pajak dalam pembayaran gaji personil penerbangan swasta.

Selandia Baru juga mengimplementasikan Omnibus Law untuk perpajakan yang tertuang dalam Taxation Act 2019. Peraturan tersebut diterbitkan untuk meningkatkan pengaturan pajak yang saat ini berlaku dalam kerangka yang luas (broad-base) dan bertarif rendah (low-rate) dalam rangka untuk mendorong kepatuhan terhadap kewajiban pajak.

Australia yang juga pernah menggunakan pendekatan omnibus. Salah satu Omnibus Law di Australia adalah Act on Implementation of US FTA yang digunakan untuk mengimplementasikan perjanjian perdagangan bebas antara Amerika Serikat dengan Australia.

Pendekatan omnibus juga diterapkan di negara yang menganut hukum sipil seperti Vietnam. Omnibus Law yang berhasil dibentuk oleh Vietnam di antaranya Law Amending and Supplementing a Number of Articles of the Law on Value-Added Tax, Law on Excise Tax and the Law on Tax Administration. Undang-undang ini mengubah, menambahkan serta mencabut beberapa pasal yang terdapat pada Undang-undang Pajak Pertambahan Nilai, Undang-undang Pajak Cukai, dan Undang-undang Administrasi Perpajakan.

Belajar dari pengalaman penerapan Omnibus Law di beberapa negara tersebut, bahwa beberapa keuntungan dengan penerapan Omnibus Law adalah antara lain: i) Pemerintah dan parlemen tidak perlu merevisi undang-undang satu per satu, melainkan cukup membuat satu undang-undang baru yang mengamendemen pasalpasal dalam beberapa undang-undang sekaligus; ii) bahwa sepanjang didahului dengan identifikasi dan pemetaan permasalahan yang komprehensif, skema Omnibus 
Law menciptakan efisiensi dan efektivitas karena menggabungkan beberapa aturan yang substansi pengaturannya berbeda menjadi suatu peraturan besar; dan iii) berfungsi sebagai payung hukum.

Namun di sisi lain, hal yang perlu diperhatikan Pemerintah adalah bahwa Omnibus Law tidak perlu menyentuh perubahan yang bersifat prinsipil dan mendasar serta memiliki implikasi terlalu besar.

Dari uraian di atas, bahwa dalam kerangka pemikiran negara kesejahteraan dibutuhkan tanggung jawab semua pihak termasuk para ahli hukum untuk menyiapkan regulasi yang berorientasi kepada kesejahteraan rakyat dan perlindungan masyarakat. Dalam penerapan Omnibus Law untuk meningkatkan investasi investasi di dalam kerangka welfare state, maka regulasi dalam Omnibus Law di Indonesia harus memberikan adanya kepastian hukum untuk meningkatkan investasi di Indonesia dalam rangka mewujudkan kesejahteraan seluruh rakyat Indonesia. Menurut Paul Rose, meningkatkan pengelolaan investasi di suatu negara menunjukkan adanya keterkaitan yang kuat antara regulasi dengan politik suatu negara, dimana hukum memberikan kepastian hukum dalam kebijakan pengelolaan investasi.(Rose, 2008)

\section{Omnibus Law sebagai Pembaharuan Hukum Investasi di Indonesia}

Nathan Roscoe Pound dalam karyanya "A Theory of Social Interest", menyatakan bahwa fungsi hukum sangat luas termasuk untuk rekonsiliasi, harmonisasi, dan kompromi atas seluruh konflik kepentingan dalam masyarakat (individu, publik dan negara), dengan prinsip hanya untuk kepentingan yang terbanyak dengan pengorbanan sekecil-kecilnya kepentingan orang lain, yang dikenal sebagai law as social engineering atau a system of social engineering. (Pound \& DeRosa, 1954) Hukum sebagai alat mengatur masyarakat, keberadaannya sama dengan eksistensi masyarakat itu sendiri, yang dari waktu ke waktu mengalami perkembangan sebagaimana masyarakat itu sendiri mengalami perkembangan.

Menurut ajaran von Savigny, hukum tumbuh, hidup dan berkembang dalam masyarakat, sedangkan menurut John Austin yang memandang hukum sebagai legal positivism yang berisi perintah dari penguasa yang berdaulat dan bagi Austin hukum tidak tumbuh, hidup dan berkembang dalam masyarakatnya sendiri, melainkan hukum dipandang sebagai alat penguasa, hukum tidak digunakan dalam fungsinya untuk tujuan hukum itu sendiri yaitu memberi keadilan. Pendapat Austin tersebut menunjukkan bahwa hukum merupakan sub sistem dari sistem kekuasaan, sehingga hukum itu tidaklah otonom.

Pandangan Austin berkorelasi dengan apa yang disampaikan Roscoe Pound yang mengemukakan konsep bahwa hukum tumbuh secara alamiah dalam pergaulan masyarakat dan hukum selalu berubah seiring perubahan sosial sebagaimana dikemukakan oleh Von Savigny.

Konsepsi hukum sebagai sarana pembaharuan sosial meyakini bahwa hukum merupakan suatu sistem yang memiliki muatan nilai baru yang bertujuan untuk mempengaruhi dan menimbulkan perubahan sosial secara terarah dan terencana. Menurut Mochtar Kusumaatmadja, hukum memiliki korelasi erat dengan pembangunan, hukum merupakan sarana pembaharuan masyarakat didasarkan atas 
anggapan bahwa adanya keteraturan atau ketertiban dalam usaha pembangunan atau pembaharuan itu merupakan sesuatu yang diinginkan atau bahkan dipandang (mutlak) perlu. (Kusumaatmadja, 2002) Hukum sebagai sarana pembangunan berpandangan bahwa hukum dalam arti kaidah atau peraturan hukum bisa berfungsi sebagai alat (pengatur) atau sarana pembangunan dalam arti penyalur arah kegiatan manusia ke arah yang dikehendaki oleh pembangunan atau pembaharuan. Hukum dan pendekatan pembangunan merupakan kunci kesuksesan dalam penerapan Omnibus Law di beberapa negara yang telah menerapkannya.

Dalam konteks gagasan penerapan Omnibus Law di Indonesia, bahwa pembentukan omnibus law ini lazim diterapkan di negara-negara yang menganut sistem common law, perlu kajian yang mendalam agar tidak menimbulkan persoalan dalam sistem penyusunan peraturan perundang-undangan. Penyisiran beberapa undang-undang dengan undang-undang yang lain yang berbeda materi dan kewenangannya perlu dilakukan secara hati-hati serta koordinasi Pemerintah dan DPR untuk mengharmonisasikannya perlu dilakukan sejak awal.

Dalam penerapan Omnibus Law, pencabutan aturan harus dilakukan secara cermat. Ketentuan penutup dari Omnibus Law harus menegaskan soal pencabutan pasal-pasal dari undang-undang terdampak agar tidak menimbulkan perdebatan konflik norma hukum.

Hal lain yang juga perlu menjadi perhatian adalah bahwa setiap undang-undang memiliki dasar filosofis, sosiologis, dan yuridis yang berbeda, sehingga pertimbangan aspek filosofis, sosiologis, yuridis aturan yang akan dicabut harus dilakukan secara cermat, khususnya yang menyangkut hak konstitusional warga negara.

Identifikasi persoalan juga harus dilakukan secara cermat. Pengubahan atau pencabutan sebaiknya dilakukan pada tataran substansi hukum, sedangkan pada tataran aspek penerapan atau budaya hukum masyarakat yang diperlukan adalah perubahan implementasi kebijakan.

Omnibus Law secara teoritis dapat menjadi solusi atas konflik peraturan perundang-undangan secara cepat, efektif, dan efisien. Namun demikian, perlu memperhatikan asas dalam peraturan perundang-undangan Indonesia yaitu asas lex posterior derogat legi priori (Undang-undang yang disahkan belakangan akan tetap bisa mengesampingkan omnibus law jika materi muatannya berbeda). Perlu harmonisasi secara hati-hati tidak hanya pada undang-undang yang akan dicabut dengan omnibus law, namun demikian dengan Rancangan Undang Undang (RUU) lain yang sedang dibahas, sehingga Peraturan Pemerintah Pengganti Undang-Undang (Perppu) bisa jadi opsi bentuk Omnibus Law.

Omnibus Law sebagai konsep pembaharuan hukum untuk meningkatkan investasi di Indonesia yang disampaikan dalam tulisan ini harus bergerak dari sistem penyusunan peraturan perundang-undangan yang ada. Proses Omnibus Law harus memperhatikan aspek yuridis, politik, sosiologi dan ekonomi. Dalam konteks yuridis, sistem perundang-undangan harus berimbang dalam aspek efektivitas dan akuntabilitas.

Dalam konteks politik, sosiologi, dan ekonomi bahwa di masyarakat masih menimbulkan polemik dan menganggap bahwa Omnibus Law akan berpotensi menimbulkan kerusakan rantai ekologis, ekonomi, dan sosial. Substansi Omnibus Law 
yang dianggap merugikan hak pekerja, pemberian kewenangan yang terlalu luas kepada Pemerintah, penyederhanaan perizinan dengan menghilangkan banyak instrumen perizinan dikhawatirkan akan menutup ruang yudikatif dalam melaksanakan fungsi kontrol guna meninjau keputusan administratif eksekutif, peralihan kewenangan perizinan dari daerah ke pemerintah pusat yang mencederai semangat desentralisasi, hilangnya beberapa ketentuan penting di bidang lingkungan (penghapusan izin lingkungan yang digabung dengan izin usaha), adalah beberapa hal yang secara sosial, ekonomi dan ekologis harus dikaji secara mendalam oleh Pemerintah dalam merumuskan Omnibus Law.

Omnibus law dalam perspektif perbandingan hukum di negara-negara lain telah memenuhi aspek efektivitas, karena dalam mekanisme Omnibus Law dilakukan perampingan dan simplifikasi dari beberapa peraturan perundang-undangan.

Dalam konteks akuntabilitas, bahwa Omnibus Law sebagai instrumen untuk mendukung pembangunan ekonomi, perlu ditegaskan peran apa yang dikehendaki oleh bidang ekonomi dari keberadaan Omnibus Law tersebut di masyarakat. Pembangunan hukum ekonomi harusnya diarahkan untuk menampung dinamika kegiatan ekonomi dengan menciptakan kegiatan yang efisien, produktif, dan mengandung daya prediktabilitas.

Omnibus Law sebagai konsep hukum dapat memberikan kontribusi dan pengaruh yang besar untuk meningkatkan investasi dan pengembangan ekonomi Indonesia apabila terdapat unsur prediktibilitas, kemampuan procedural, kodifikasi tujuan, factor penyeimbangan, akomodasi, dan definisi dan kejernihan tentang status sebagaimana disampaikan oleh ahli hukum J.D. Ny Hart.

Menurut pemikiran J.D. Ny Hart terdapat enam konsep dalam ilmu hukum yang mempunyai pengaruh bagi pengembangan ekonomi, yaitu:

a. Prediktabilitas, bahwa hukum harus mempunyai kemampuan untuk memberikan gambaran pasti di masa depan mengenai keadaan atau hubungan-hubungan yang dilakukan pada masa sekarang;

b. Kemampuan procedural, bahwa pembinaan di bidang hukum acara memungkinkan hukum material itu dapat merealisasikan dirinya dengan baik ke dalam pengertian hukum acara ini termasuk tidak hanya ketentuan ketentuan hukum perundang-undangan, melainkan juga semua prosedur penyelesaian yang disetujui oleh para pihak yang bersengketa, misalnya bentuk-bentuk arbitrasi, konsiliasi, dan sebagainya;

c. Kodifikasi tujuan-tujuan, bahwa perundang-undangan dapat dilihat sebagai suatu kodifikasi tujuan serta maksud sebagaimana dikehendaki oleh negara. Misalnya di bidang ekonomi, kita akan dapat menjumpai tujuan-tujuan itu seperti dirumuskan di dalam beberapa perundang-undangan yang secara langsung atau tidak langsung mempunyai pengaruh terhadap bidang perekonomian;

d. Faktor penyeimbangan, bahwa sistem hukum harus dapat menjadi kekuatan yang memberikan keseimbangan di antara nilai-nilai yang bertentangan di dalam masyarakat. Sistem hukum memberikan "kesadaran akan keseimbangan" dalam usaha-usaha negara melakukan pembangunan ekonomi; 
e. Akomodasi, bahwa perubahan yang cepat sekali pada hakikatnya akan menyebabkan hilangnya keseimbangan yang lama, baik dalam hubungan antar individu maupun kelompok di dalam masyarakat. Sistem hukum memberikan pegangan kepastian melalui perumusan-perumusan yang jelas dan definitive, membuka kesempatan bagi dipulihkannya keadilan melalui prosedur yang tertib dan sebagainya; dan

f. Definisi dan kejernihan tentang status. Bahwa fungsi hukum memberikan ketegasan mengenai status orang-orang dan barang barang di masyarakat.(Rahardjo, 1980)

Pembaharuan hukum dalam konsepsi Omnibus Law untuk meningkatkan investasi di Indonesia harus dilakukan secara efektif dan akuntabilitas.

Omnibus Law dalam pemahaman instrumentalis-demokratis, bahwa di satu sisi dapat digunakan sebagai "tools" dan berorientasi pada pemenuhan dan penguatan nilai-nilai negara hukum (rule of law) yang berorientasi jangka panjang sekaligus mencipta iklim demokrasi-partisipatoris yang berkelanjutan. Dalam pemahaman instrumentalis-demokratis, tradisi hukum perundang-undangan (common law dan civil law) tidak dipandang sebagai sistem yang terpisah. Karena faktanya kedua tradisi tersebut telah lama saling meminjam pengalaman (konvensi), konsep, dan praktik ketatanegaraan satu sama lain (constitutional borrowing).

Omnibus law dapat berperan efektif mengurangi disharmonisasi dan konflik norma dalam perundangan-undangan, namun di sisi lain juga memiliki legitimasi demokratis yang akuntabel lewat mekanisme uji publik dan partisipasi publik yang luas dan dilakukan dengan prinsip kehati-hatian. Guna menjamin prinsip kehati-hatian dalam perumusan perundangan-undangan, maka Omnibus Law harus dirumuskan dengan terlebih dulu melakukan upaya konsolidasi norma-norma, definisi-definisi konseptual, dan menetapkan subjek yang akan menjalankan undang-undang Omnibus Law tersebut.

Terobosan Pemerintah dengan menginisiasi Omnibus Law akan efektif apabila mendasarkan pada asas-asas perundangan-undangan yang bersemangat rule of law serta taat pada nilai-nilai dan kepentingan-kepentingan kemanusiaan yang berkelanjutan. Advokasi dari seluruh elemen bangsa dalam tataran perumusan dan implementasi Omnibus Law akan mampu mewujudkan peningkatan investasi di Indonesia yang pada akhirnya akan mewujudkan kesejahteraan bagi seluruh rakyat Indonesia.

\section{CONCLUSION}

1. Politik hukum merupakan konsep dan asas yang menjadi garis besar dan dasar rencana pelaksana negara dalam hal pembentukan dan pelaksanaan kebijakan legislasi yang bersumber pada nilai-nilai yang berkembang di masyarakat untuk mencapai tujuan bernegara sesuai dengan Pancasila dan Undang-Undang Dasar 1945 harus tercermin dalam upaya pembaharuan hokum dalam Omnibus Law untuk meningkatkan investasi di Indonesia.

2. Omnibus Law sebagai upaya Pemerintah dalam meningkatkan investasi di Indonesia untuk meningkatkan kesejahteraan seluruh rakyat Indonesia dalam perumusan 
maupun implementasinya harus berimbang dalam tataran efektivitas dan akuntabilitas dengan memperhatikan aspek yuridis, politik, sosiologi dan ekonomi.

\section{REFERENCES}

Aikins, S. (2009). Global financial crisis and government intervention: A case for effective regulatory governance. International Public Management Review, 10(2), 23-43.

Anggono, B. D. (2020). Omnibus Law Sebagai Teknik Pembentukan Undang-Undang: Peluang Adopsi Dan Tantangannya Dalam Sistem Perundang-Undangan Indonesia. Jurnal RechtsVinding, 9(1).

Chen, S., Sun, Z., Tang, S., \& Wu, D. (2011). Government intervention and investment efficiency: Evidence from China. Journal of Corporate Finance, 17(2), 259-271.

Duchin, R., \& Sosyura, D. (2012). The politics of government investment. Journal of Financial Economics, 106(1), 24-48.

Frenki, F. (2011). Politik Hukum Dan Perannya Dalam Pembangunan Hukum Di Indonesia Pasca Reformasi. ASAS, 3(2).

Holmes, P. (2014). The politics of law and the laws of politics: The political paradoxes of transnational constitutionalism. Indiana Journal of Global Legal Studies, 21(2), 553583.

Kim, H. (2010). Political stability and foreign direct investment. International Journal of Economics and Finance, 2(3), 59-71.

Kurniati, P. N. (2018). Urgensi Reformasi Birokrasi dan Reformasi Regulasi dalam Membangun Tata Kelola Ekonomi di Indonesia. Jurnal Analis Kebijakan, 2(1).

Kusumaatmadja, M. (2002). Fungsi dan Perkembangan Hukum Dalam Pembangunan Nasional (Dalam Buku Konsep-konsep Hukum Dalam Pembangunan). Edisi Pertama, Cetakan Kesatu, Alumni, Bandung.

Mahfud Md, M. (2006). Membangun Politik Hukum, Menegakkan Konstitusi. Pustaka LP3ES. Jakarta.

Mayasari, I. (2020). Kebijakan Reformasi Regulasi Melalui Implementasi Omnibus Law Di Indonesia. Jurnal Rechts Vinding: Media Pembinaan Hukum Nasional, 9(1), 1.

Pavolini, E., \& Ranci, C. (2008). Restructuring the welfare state: Reforms in long-term care in Western European countries. Journal of European Social Policy, 18(3), 246-259.

Pound, R., \& DeRosa, M. L. (1954). An introduction to the philosophy of law (Vol. 10). Yale University Press.

Prasetyo, K. F. (2016). Politik hukum di bidang ekonomi dan pelembagaan konsepsi welfare state di dalam Undang-Undang Dasar 1945. Jurnal Konstitusi, 9(3), 495-514.

Rahardjo, S. (1980). Hukum dan masyarakat. Angkasa. 
Rose, P. (2008). Sovereign wealth fund investment in the shadow of regulation and politics. Geo. J. Int'l L., 40, 1207.

Sastradipoera, K. (2007). Sejarah Pemikiran Ekonomi: Suatu Pengantar Teori dan Kebijaksanaan Ekonomi. Bandung: Kappa-Sigma.

Syaukani, I., \& Thohari, A. A. (2013). Dasar-dasar politik hukum. Divisi Buku Perguruan Tinggi, RajaGrafindo Persada.

Tohadi, T. (2020). Kajian Kritis Atas Kewenangan Presiden Untuk Membatalkan Peraturan Daerah Dalam Omnibus Law. Jurnal Rechts Vinding: Media Pembinaan Hukum Nasional, 9(1), 125.

Wahyono, P. (1984). Masalah Ketatanegaraan Indonesia Dewasa Ini. Ghalia Indonesia. 